\title{
CLARICE LISPECTOR E O DIÁLOGO ENTRE LINGUAGENS
}

Rodrigo Costa ARAÚJO Faculdade de Filosofia Ciências e Letras de Macaé rodricoara@uol.com.br

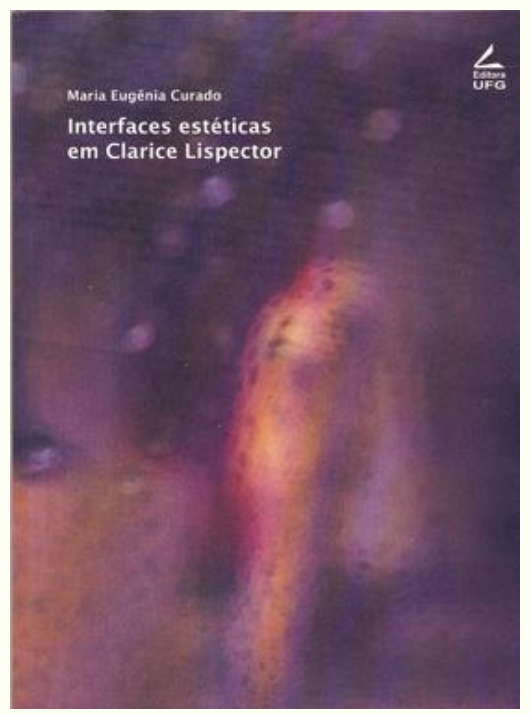

Capa do livro

Interfaces estéticas em Clarice Lispector

CURADO, Maria Eugênia. Interfaces estéticas em Clarice Lispector. Goiânia: Editora UFG, 2010.

O livro Interfaces estéticas em Clarice Lispector (2010), de Maria Eugênia Curado já confessa, antecipadamente, pelo título/paratexto que carrega, a leitura da poética de Clarice Lispector (1925-1977) por diversos vieses. Especificamente pelas correspondências e transformações entre literatura, artes plásticas e cinema.

O prefácio - "A expressão do mundo por múltiplas linguagens" -, de Olga de Sá que apresenta a obra revela as sutilizas e as aproximações que Maria Eugênia faz dos aspectos visuais da escritura de Clarice Lispector e das contribuições para as análises do signo não verbal.

Dessas aproximações surgem leituras não lineares e que, por isso mesmo, exigem do intérprete uma capacidade de se expressar e de colher a dialogia entre signos, permitindo, segundo Olga de Sá, a percepção dialética que se estabelece entre idas e vindas do texto e da leitura. Em tal dialogia, 
surge a possibilidade de estabelecer a relação entre o texto visual e o não verbal a partir do questionamento de um mundo visto e expresso além da superfície.

O livro, em sua estrutura, divide-se em cinco partes. A primeira - que explica as possibilidades de correspondências entre linguagem verbal e não verbal - é a porta de entrada de leituras imbricadas entre signos.

A segunda e terceira partes centram-se no surrealismo em Clarice Lispector e das relações com pintor belga René Magritte (1898-1967). Nestes capítulos, é desenvolvido o percurso histórico da poética surrealista, apontando semelhanças com a poética clariciana. Destacam-se, desse jogo criativo de aproximações poéticas, as metáforas insólitas, o processo metonímico do texto, o fluxo de consciência e a ruptura com o enredo factual, além do caráter incomum e enigmático da prosa de Clarice.

Feito Clarice, movimentos semelhantes são verificados em Magritte. Suas telas fundem, por vezes, de forma explícita, o desejo de filosofar a representação e a busca de uma imagem que revele os problemas do representado. O pintor belga "pintograma" os problemas da linguagem, do objeto e do interpretante, revelando a nossa precipitada noção de leitura, normalidade perceptiva e linearidade estética.

O quarto e quinto capítulos privilegiam as aproximações no último romance da escritora e na transcrição fílmica de Suzana Amaral. A estudiosa aponta como as páginas do romance $A$ Hora da Estrela se converteram em cenas, recortes os quais a cineasta imprimiu leituras especulares, presentes tanto no texto de Clarice quanto na pintura de Magritte.

A obra, de certa forma, é um exercício de leitura centrado, ludicamente, nos códigos verbal e imagético. Magritte, como Clarice, filosofa por imagens e suas telas questionam, em geometrias, formas e cores, a vertigem da leitura superficial do cotidiano que torna óbvio o que é, na verdade, codificado. Clarice, feito o pintor belga, aponta não apenas para o onírico na ficção, mas quer pensar por imagens a ilusão que a leitura dos signos nos provoca. Suzana Amaral (re)lê em Clarice o impossível de presenciar, de conduzir e, mais ainda, de traduzir. Instiga, de certa forma, as inquietudes da linguagem e do livro para 
a tela. A crítica, por sua vez, desconstrói as concepções canônicas acerca do texto (verbal e não verbal), aponta para a brincadeira com a linguagem, para o prazer da semiose e dos jogos intertextuais.

Enfim, o estudo está organizado de forma a compor um quadro amplo das relações/correspondências entre os textos e sobre os diferentes modos de realização dessas aproximações, para desembocar na poética clariciana, cujo título do livro já explicita o olhar dialógico, isto é, uma das vertentes da rede de relações entre textos e linguagens, objeto do estudo fundamentado pela semiótica de Peirce.

Interfaces estéticas em Clarice Lispector (2010) é, em muitos sentidos, mais que uma leitura crítica, um elogio das fricções. Por meio de aproximações e da delicada sintaxe visual, projeta a poética clariciana irradiada sobre a circulação dos diversos fragmentos, dando visibilidade incomum, rara entre nós, ao diálogo intertextual entre as artes. Essa cartografia visual e afetiva, então, desenhada e mapeada por Maria Eugênia Curado repercute, para o leitor/espectador, em respostas que se abrem para outras indagações. Por isso, teoria crítica, objeto de estudo e valorização da prosa clariciana se unem neste ensaio de forma a estabelecer bases para uma leitura perspicaz e mais atualizada da literatura e de outras linguagens da arte.

\section{Referências bibliográficas}

CURADO, Maria Eugênia. Interfaces estéticas em Clarice Lispector. Goiânia: Editora UFG, 2010.

Resenha recebida em: 31 de março de 2013.

Resenha aprovada em: 30 de junho de 2013.

\section{Sobre o autor:}

Doutorando em Literatura Comparada e Mestre em Ciência da Arte pela Universidade Federal Fluminense. 